\title{
Pengembangan Konsep Comprehensive Life Style Intervention pada Tatanan Sekolah melalui Program Gerakan Jajan Sehat (GJS) di SD Negeri 01 Baruga Kota Kendari
}

Nurhijrianti Akib*

*Program Studi S2 IImu Kesehatan Masyarakat Fakultas Kedokteran, Kesehatan Masyarakat, dan Keperawatan Universitas Gadjah Mada

\section{Latar Belakang}

Jajan merupakan perilaku yang sering dikakukan oleh siswa khususnya siswa sekolah dasar, yang dapat mutu gizi, kebersihan, dan keamanan pang (1-2), Berdasarkan sampling dan uii laborahan terhadap 10.429 sampel jajanan yang diambil dari 144 Sekolah Dasar/Madrasah Ibtidaiyah di 31 provinsi seluruh Indonesia yang dilakukan on Pengawas Obat dan Makanan (BPOM) tahun 2014, tercatat bahwa $2.484(23,8 \%)$ dari sampel jajanan tersebut tidak memenuhi syarat, disebabkan karen kandungan bahan tambahan yang berbahaya ${ }^{(3)}$.

Selain itu, penggunaan air yang tidak bersih serta minyak goreng yang telah dipakai berkali-kali juga sangat berbahaya. Makanan yang lidak aman ini dapat menimbulkan berbagai penyakit, seperti diare, rang sering mengkonsumsi jajakn yang sering mengkonsumsi jajanan malas untuk mengonsumsi sayuran dan makanan bergizi lainnya izka kecukupan gizi tidak

\section{Tujuan}

Umum: Membentuk dan mengembangkan Gerakan Jajan Sehat (GJS) di SD Negeri 1 Baruga Kota Kendari dalam jangka waktu 6 bulan intervensi.

Khusus: (1) Sekurang-kurangnya $50 \%$ siswa mengalam eningkatan pengetahuan tentang jajan sehat.

(2) Sekurang-kurangnya $50 \%$ siswa mengalami perubahan sikap tentang jajan sehat.

\section{Gagasan yang Diajukan}

Pengembangan program Gerakan Jajan Sehat (GJS) yang didasari oleh Konsep Comprehensive Life Style Intervention dari Ottawa Charter yang mencakup 5 dimens yaitu(6)

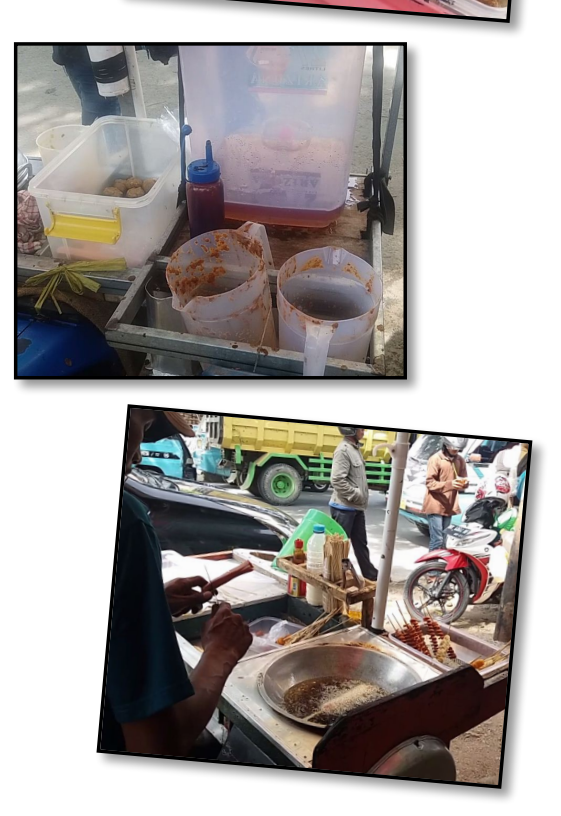

SD Negeri 01 Baruga Kota Kendari merupakan salah satu sekolah dasar yang berdasarkan hasil observasi, masih memiliki perilaku jajan yang belum baik. Karena itu, perlu dilakukan upaya untuk mengatasi masalah ini salah satunya dengan mengembangkan "Gerakan Jajan Sehat" pada siswa sekolah ini, yang di dalamnya terdapat intervensi yang kompherensif untuk membentuk perilaku jajan yang baik di tatanan sekolah Penerapan kebijakan kesehatan

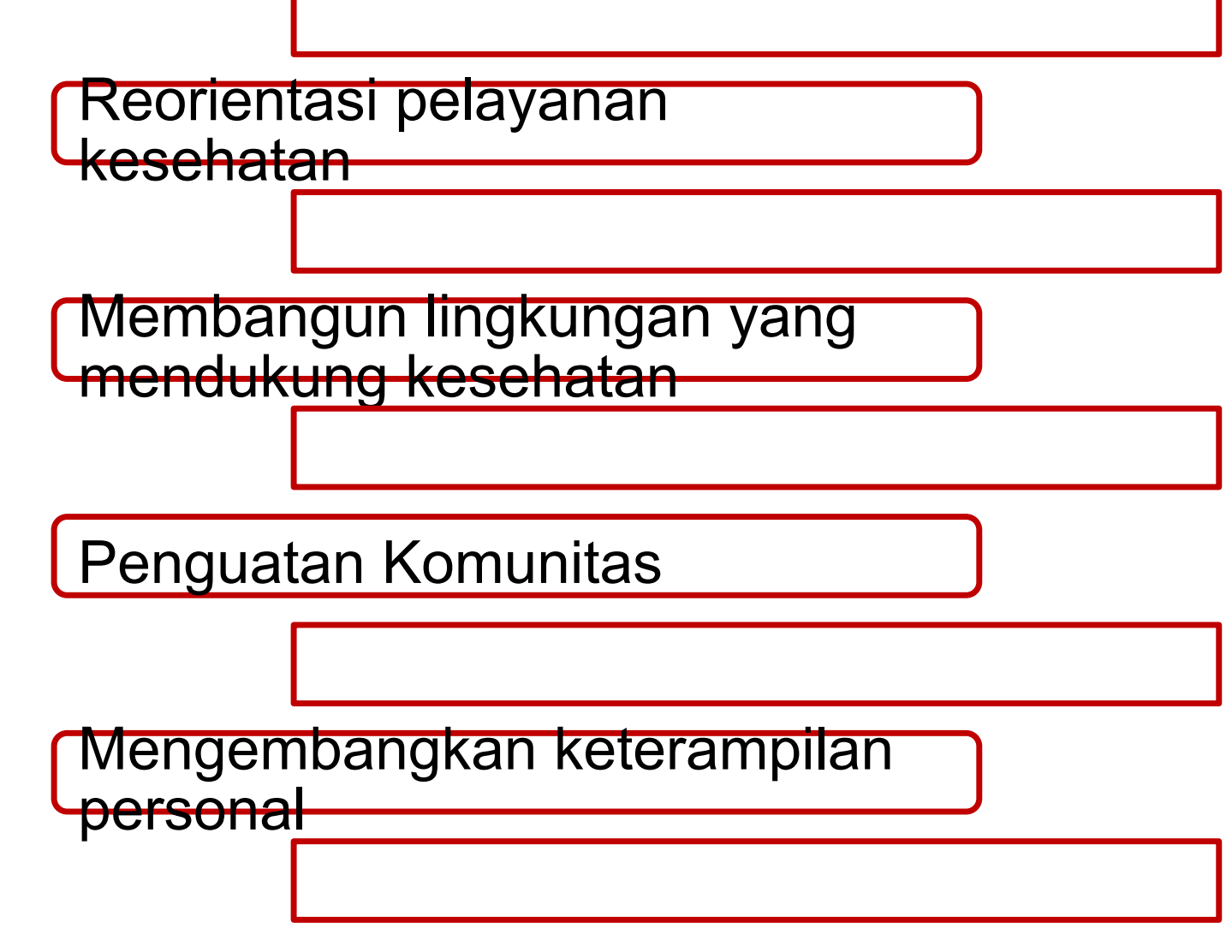

5 dimensi ini merupakan implementasi intervensi yang sistematik dan kompherensif , yang diterapkan kepada sehat.

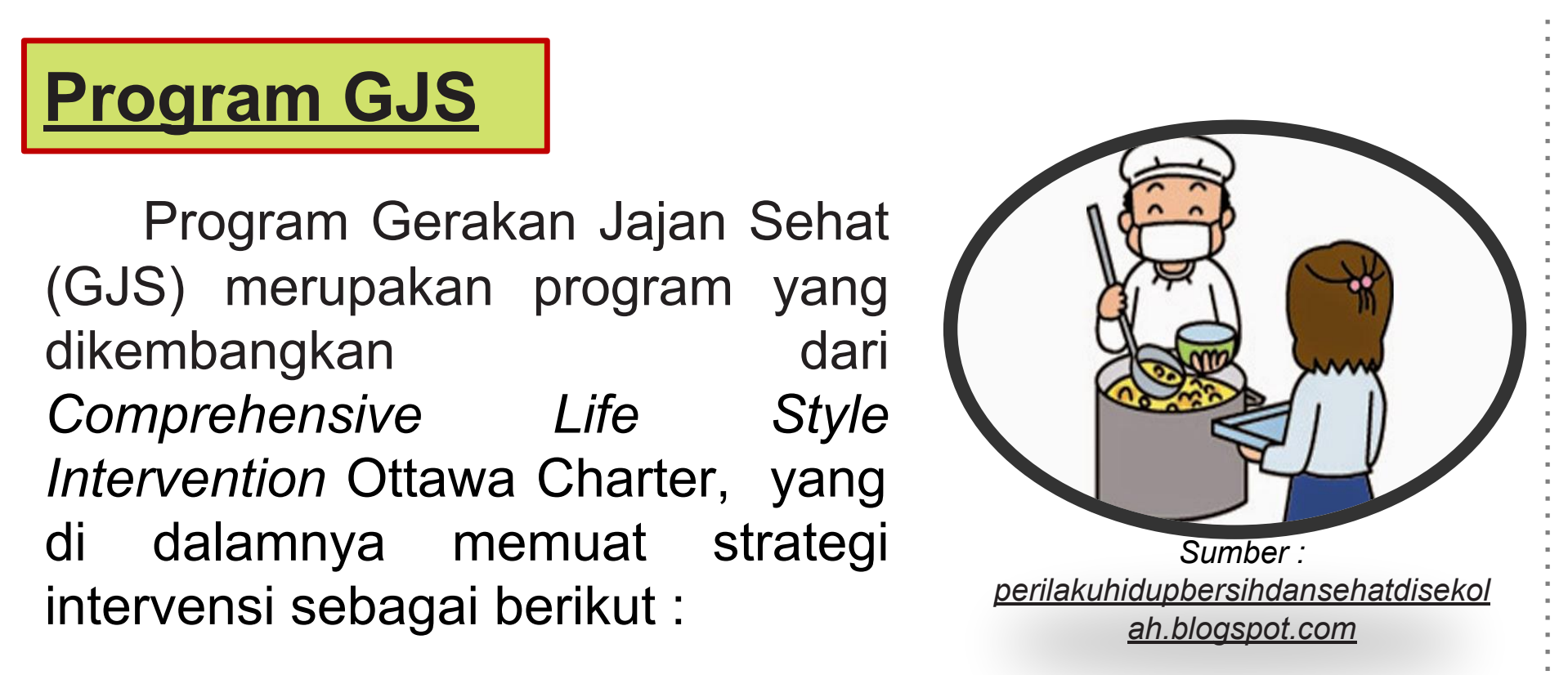

1. Penerapan kebijakan kesehatan: seluruh siswa sekolah untuk membentuk perilaku jajan yang -Aturan pelarang penjualan makanan tidak sehat. - Menjual makanan yang sehat di sekolah.

2. Reorientasi pelayanan kesehatan: gan prinsip preventif. Pemeriksaan kesehatan untuk siswa.

3. Membangun lingkungan yang mendukung kesehatan

Lesson Learned

Perilaku jajan siswa tidak terbentuk begitu saja, melainkan karena banyak faktor yang saling berinteraksi baik itu pengetahuan, lingkungan, sampai peranan orang tua dan guru. ini dapat menjadi salah satu solusi yang efektif untuk meningkatkan pengetahuan dan sikap siswa tentang jajanan tuk mencegah terjadinya masa oleh perilaku jajan yang salah.

\section{Rekomendasi}

Program GJS diharapkan dapat dikembangkan di SD Neger 01 Baruga Kota Kendari, melalui advokasi yang melahirkan kesepakatan dengan pihak sekolah dalam hal pelaksanaannya selama masa intervensi yang telah ditentukan. Selanjutnya program dievaluasi baik proses maupun hasilnya. Jika terbukti dapat mencapai tujuan yang telah ditetapkan dan program dinilai berhasil, maka selanjutnya program dapat diadopsi dan diterapkan oleh sekolah-sekolah lainnya, untuk meningkatkan derajat kesehatan siswa.

sudut sekolah.

-Pendidikan kesehatan kepada staff sekolah dan guru.

Pengembangan "Kantin Sehat".

-Penyediaan makanan sehat pada program "Kamis Sehat".

4. Penguatan aksi di komunitas:

Mengintegrasikan perilaku sehat yang didapatkan di sekolah ke rumah, begitupun sebaliknya.

-Pendidikan kesehatan tentang jajanan yang sehat kepada orang tua melalui whatsapp group.

5. Mengembangkan keterampilan personal:

-Penyuluhan tentang bahaya jajan sembarangan dengan media audiovisual.

-Pendidikan kesehatan dengan metode permainan "Kartu Jajanan Sehat"

-Pendidikan kesehatan dengan metode permainan "Papan Nutrisi Makanan Sehat"

\section{Referensi}

Cortese, R., Veiros, M., Feldman, C., Cavalli, S. (2016). Food safety and hygiene cross-sectional study. Food Control 62 (2016) 178-186.

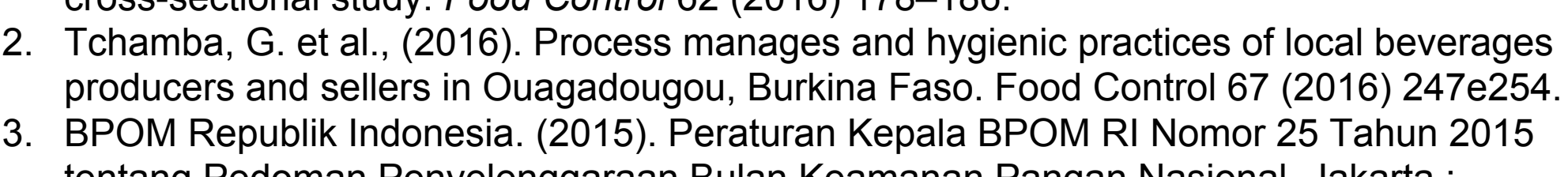
tentang Pedoman Penyelenggaraan Bulan Keamanan Pangan Nasional. Jakarta :
BPOM RI.

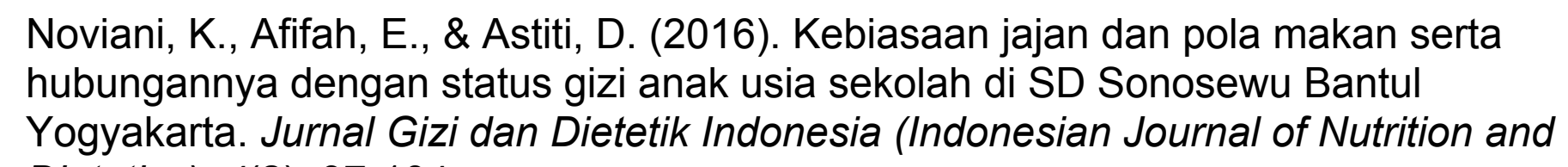
5. Daik,., , Lee, H. (2016). Habitual plate-waste of 6 - to 9-year-olds may not be associated
with lower nutritional needs or taste acuity, but undesirable dietary factors. Food Control
62 (2016) $178-186$. Kalantari, N., Mohammadi, N.K. Rafieifar, S., et al., (2017). Indicator for Success of
Obesity Reduction Programs in Adolescents: Body Composition or Body Mass Index? Evaluating a School-based Health Promotion Project fafter 12 Weeks of Intervention.
International Journal of Preventive Medicice 2017.873 